\title{
The Austrian Electronic Economic Chamber
}

\author{
Christian Rupp \\ Austrian Federal Economic Chamber, Vienna, Austria
}

\author{
Christian.Rupp@wko.at
}

\begin{abstract}
1994 the Austrian Federal Economic Chamber has started to build an interactive portal on the internet (wko.at). This portal is at the moment one of the greatest information and know-how platforms in Europe and a combination between eGovernment and eBusiness. More than 370.000 companies have access to an extranet which includes more than 700.000 pages online. More than 1.000 organisations within the Chamber Network and their employees have access to an intranet and upload daily their information worldwide. Around 12.000.000 visitors per month download information in the field of law, business news, statistics and other content like WebTV, or use an eMarketplace. On the international side wko.at has business information about austrian products in 19 languages online. Online legislative projects as well as administrative procedures and other interactive possibilities are also implemented. The content of WKO.at also appears in many other Austrian ePlattforms. Therefore wko.at is a best practice example of eAustria in eEurope.
\end{abstract}

Keywords: eGovernment, eBusiness, Chamber Network Portal, Know-How Management Platform, eAustria, eEurope

\section{Introduction}

The Austrian Federal Economic Chamber (WKO) coordinates and represents the interests of the Austrian business community on the national and international level.

Membership is compulsory and comprises all Austrian companies (some 300.000 businesses drawn from the areas of trade and crafts, commerce, industry, transportation, tourism, finance, services industries, finance and insurance).

Main tasks and activities are

- representation of membership interests at all levels of government (by law governments are obliged to consult with WKO on legislative projects and important regulation or to involve WKO in decisionmaking and administrative procedures),

- information and advisory service to members (taxation, labour law, vocational training, legislation, advertising, market research),

- economic and international trade promotion/support at the national level (70 field offices around the

Material published as part of these proceedings, either on-line or in print, is copyrighted by Informing Science. Permission to make digital or paper copy of part or all of these works for personal or classroom use is granted without fee provided that the copies are not made or distributed for profit or commercial advantage AND that copies 1) bear this notice in full and 2) give the full citation on the first page. It is permissible to abstract these works so long as credit is given. To copy in all other cases or to republish or to post on a server or to redistribute to lists requires specific permission from the publisher at Publisner@intormingscience.org world).

\section{Austrian Electronic Economic Chamber}

1994 WKO has started to build an interactive portal on the internet (wko.at). This portal is at the moment one of the greatest information and know-how 


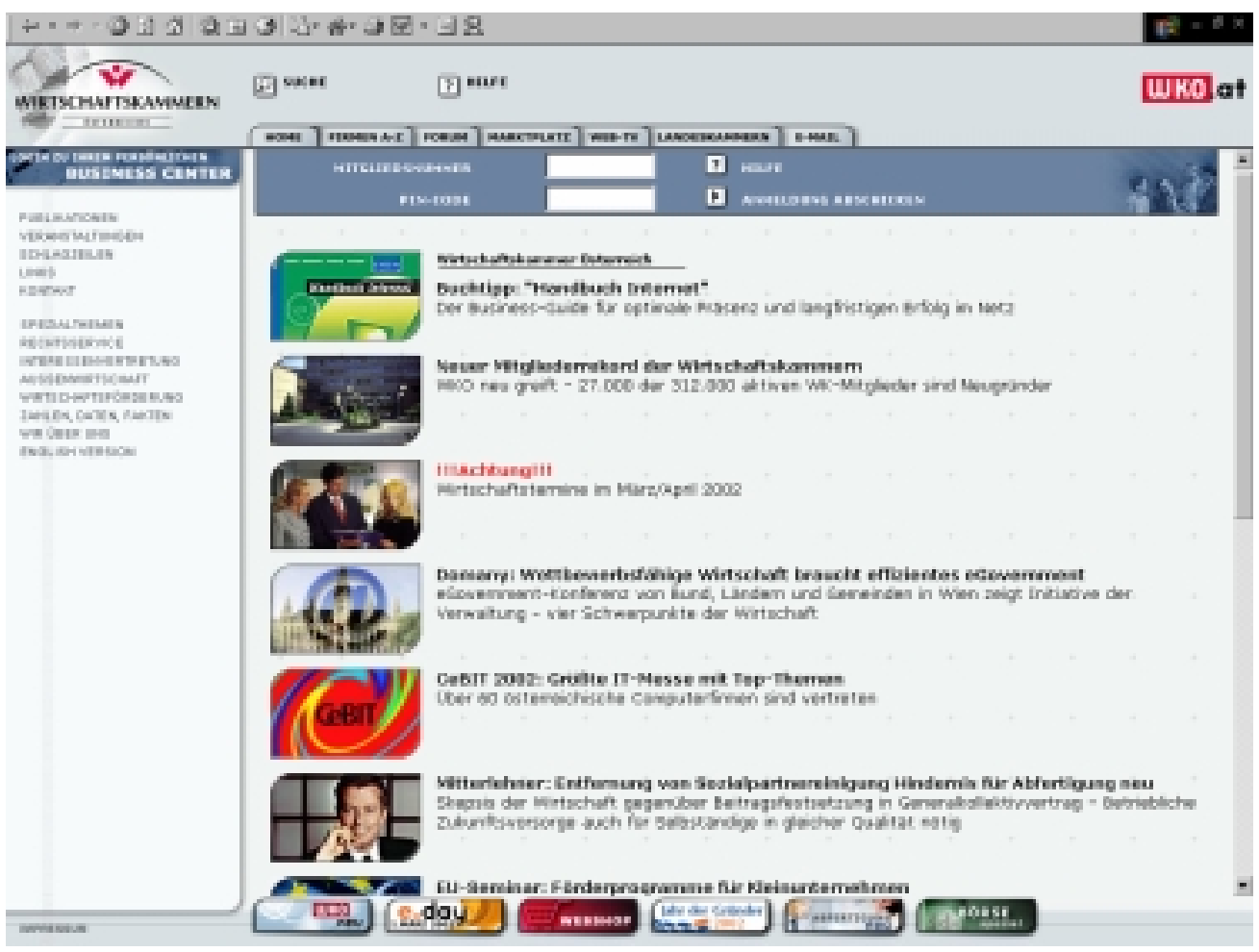

Figure 1: WKO Portal

platforms in Europe and a combination between eGovernment and eBusiness. (See Figure 1.)

More than 1.000 organisations within the Chamber Network and their employees have access to an intranet and upload worldwide their information daily. The background is a unique editorial system. From everywhere of the world all our employees can upload information for intranet, extranet or internet platforms without HTML knowledge or FTP software.

More than 370.000 companies have access to an extranet (with their own password each company has their own individual and personal homepage) which includes more than 700.000 pages online (also by WAP).

Around 12.000.000 visitors per month download information in the field of law, business news, statistics and other content like WebTV. Important conferences are transferred live to the internet community as well as featured with video conferences.

On the international side WKO.at has business information about every country in the world as well as information about Austrian products in 19 languages online.

\section{Internet and eBusiness in Austria (Facts and Figures)}

At the end of the 4rd Quarter 2001 there are approx. 3.550.000 Internet users in Austria and 84\% of the Austrian companies have access to the internet. In the 4rd Quarter $200161 \%$ (1996: $36 \%$ ) of the Austrian households were equipped with personal computers (approx. 1.920.000) and 92\% of the Austrian companies. (See Figures 2 and 3.) 


\section{Internet Use in Austria $1996-2001$}

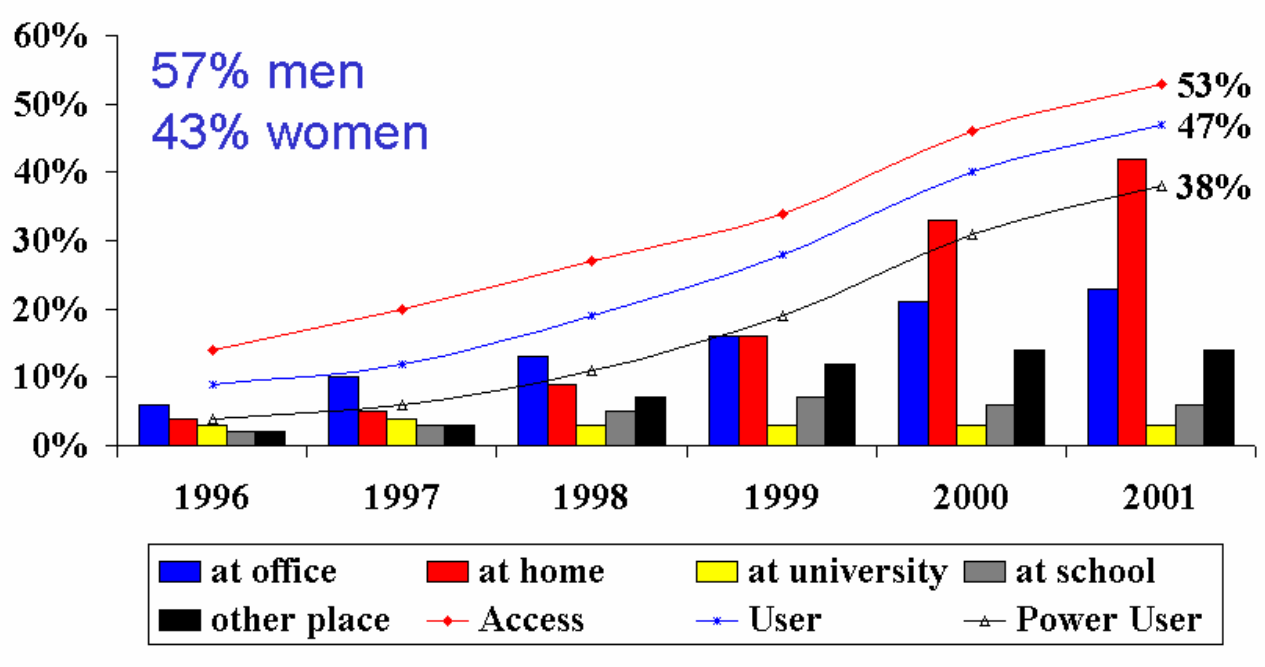

Source: Austrian Internet Monitor in percentage of the austrian population over the age of fourteen

Figure 2: Internet Use in Austria (Www.gfk.at)

\section{Projects and Examples of eGovernment in eAustria}

WKO offers also an eMarketplace, eLearning and eConsulting. Many online legislative projects as well as administrative procedures and other interactive possibilities have been started with ministries like „Lets eBiz“, ,eFIT“, ,Telefit“, „Finance Online“ and „Statistic Online“. The content of WKO.at appears in many other Austrian ePlatforms and is a best practice example of eAustria in eEurope.

At the beginning of 2001 the Austrian Federal Economic Chamber is also a registration office for the digital signature.

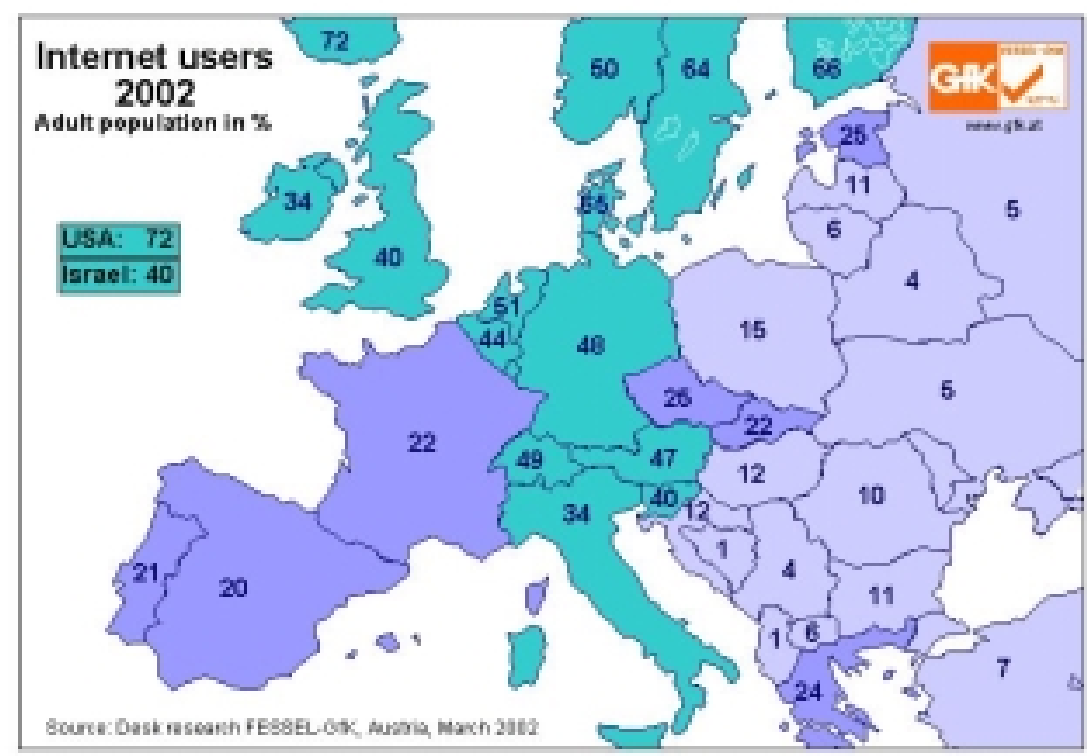

Figure 3: Internet User in Europe (www.gfk.at) 


\section{The Administration Gateway of the City of Salzburg}

The City of Salzburg has an Internet service platform, which includes:

- e-finance for taxes,

- e-file for permissions,

- geographical information system for digital plans

Web site: http://www.stadt-salzburg.at/egovernment

\section{Job-Room - Interactive Service Platform for Jobseekers and Employers}

The Public Employment Service Austria (AMS Österreich) offers the eJob-Room service at WWW.ams.or.at, an interactive service platform for job seekers and employers. At www.jobroom.at they receive support in the labour-matching process. The site's main features include two-way online interaction and full transactions. At WwW.bewerbungscoach.at the AMS's website offers additional support with the drawing up of CVs and job applications. Also, there are special interest sites for women as 50\% of users on WWW.ams.or.at are female, an info-page on employment for older people and a tool for ITspecialists.

The European dimension is ensured by the fact that there is information on work in Austria as well as in Europe (via Eures job search). Occupational and geographical mobility is promoted. The importance of this site is further underlined by the fact that, whereas currently $10 \%$ of vacancies are filled via the Internet, this medium's share will rise to up to $25 \%$ within the next three to five years.

Web site: http://WWW.ams.or.at

\section{ELC - Electronic Legal Communication}

The Electronic Legal Communication (ELC) is the structured paperless electronic communication between parties and courts and vice versa. ELC is a real substitute of traditional paper communication with the same legal value.

Web site: http://www.datakom.at/erv

\section{CCM - Central Complaint Management}

The CCM application records and collects requests, complaints and suggestions of the citizens of Vienna concerning all cases related to the Vienna City Administration (VCA). It facilitates quick and efficient response to the citizens and provides one pool of information for all employees of VCA.

Web site: http://wWw.magwien.gv.at

\section{RinderNET}

The application provides online-issue of 'cattle passports' and allows different user access levels providing the most important information on both cattle and holdings: the history of every cattle can be traced to any given date and a complete information on every stock holder is available including reports to the database, available ears tags on holding, status of premium, findings of control-checks and so on.

Web site: $\quad$ WWW.rindernet.at 


\section{Applications under the Vienna Law on Land Acquisition by Foreign Citizens}

Applications by foreign citizens for permission to acquire land in Vienna are submitted to the Municipal Department by electronic upload. This is usually done by the applicant's legal representative. Once the applicant has proven eligible, the user can complete the necessary forms, which are available on the Internet. Further documents to be submitted with the application (office copies of the land register entry, plan of the estate, sales contract, passport, additional motives or explanations etc.) can be scanned and uploaded as files.

Web site: http://WWW.magwien.gv.at/fremde/aus/grd.htm

\section{Conclusions}

The IT world is confronted with decreasing prices for bandwidth and computer power but with an increasing number of internet users. Technology will loose their importance in comparison with the importance of information. The function of a Chamber Organisation is to strengthen intermediary function and to select value added information. We have to prepare this information to guarantee easy access and easy understanding for SMEs. Therefore we need logistic and technology (language processing, agent technology). Our function for the future will be to provide SMEs with functions like digital signature and e-cash systems that they are prepared for the eFuture.

\section{References}

Prorok T., Sallmann R. (2002). E-Government - Introduction for Austrian Citizen and Areas, ISBN 3-901683-15-1

Rupp C. (2002). Business Online - A guide through the internet marketplace, ISBN 3-901688-30-7

Rupp C. et al. (2001). Austria Online 2002, ISBN 3-901688-32-3

\section{Biography}

The author Christian Rupp is eBusiness representative of the Austrian Federal Economic Chamber since 1995. He is evaluator in the eEurope Programme of the European Commission and national expert in some EU-Projects. Furthermore he is central registration officer for the digital signature and deputy head of the communication department. He has published some books and articles like Austria Online (1998, 1999, 2000, 2001, 2002), Business Online (2002), Jobs Online (2001) or Handbook Internet for SME (2000) and was keynote speaker in different conferences in Europe and the United States in the last years. 